\title{
INTERNATIONAL DECISIONS
}

\author{
Edited By Julian Arato
}

\begin{abstract}
African Court on Human and Peoples' Rights-Universal Declaration of Human RightsInternational Covenant on Civil and Political Rights-African Charter on Democracy, Election and Good Governance —right to freedom of association—right to nondiscrimination and free practice of religion
\end{abstract}

Houngue Éric Noudehouenou v. Republic of Benin. App. No. 003/2020. At https://www. african-court.org/en/images/Cases/Judgment/003-2020 Houngue_Eric_Noudehouenou_ v_Benin-_Judgment.pdf.

African Court of Human and Peoples' Rights, December 3, 2020.

The judgment in Houngue Éric Noudehouenou v. Republic of Benin ${ }^{1}$ adds to the growing body of human rights jurisprudence on national electoral processes in Africa's international courts. ${ }^{2}$ Houngue Noudehouenou's (Houngue) case was sparked by a series of amendments to the 1990 Constitution of the Republic of Benin (Benin), Law No. 2019-40 (Revised Constitution), and changes to Benin's electoral law (para. 1). ${ }^{3}$ Houngue argued that the cumulative effect of the amendments violated his right to stand for election in the upcoming 2021 presidential election as an independent candidate, as well as his right to freedom of expression and freedom of association.

The decision demonstrates the growing importance of Africa's regional and subregional courts as an alternative venue for opposition politicians, activists, and citizens to mobilize and challenge election processes and constitutional amendment processes where the playing field in their state is uneven. In turn, it reinforces the pivotal role of the regional and

\footnotetext{
${ }^{1}$ Houngue Éric Noudehouenou v. Republic of Benin, App. No. 003/2020, Judgment (Afr. Ct. Hum. Peoples' Rts. Dec. 4, 2020), available at https://www.african-court.org/en/images/Cases/Judgment/003-2020Houngue_Eric_Noudehouenou_v_Benin-_Judgment.pdf.

${ }^{2}$ James Gathii \& Jacquelene Mwangi, The African Court of Human \& People's Rights as an Opportunity Structure, in James Gathit, The Performance of Africa's International Courts: Using Litigation for Political, Legal, AND Social Change (2020).

${ }^{3}$ Among other claims, the Houngue argued that the elections to the National Assembly conducted pursuant to Law No. 2018-31 of September 3, 2018 was neither transparent nor conducted in compliance with the Revised Constitution and the Electoral Code. Previous attempts in 2006, 2011, and 2017 to amend the 1990 Constitution were met with popular resistance and dismissed by Benin's Constitutional Court. To circumvent this, the government appointed a new Constitutional Court president, who many believed was close to President Patrice Talon, having previously been his private lawyer. David Zounmenou, Crisis of Confidence in Benin Deepens, Inst. SEC. STUD. (Dec. 17, 2020), at https://issafrica.org/iss-today/crisis-of-confidence-in-benin-deepens.
} 
subregional courts in consolidating democratic governance in Africa, and reveals the limits of assessing the performance of Africa's international courts solely on conventional measures of effectiveness and compliance. ${ }^{4}$

The African Court's decision arrives in the shadow of Benin's socio-political crisis and only a few months before the April 2021 presidential elections. Houngue's case also needs to be situated in the context of the country's recent parliamentary and municipal elections. Benin is one of the first states in Africa to introduce multiparty elections. However, Benin's electoral success $^{5}$ and democratic health has slipped since President Patrice Talon took power in 2016. ${ }^{6}$ Under President Talon's watch, Benin has grown increasingly repressive: free speech has been curtailed, and intimidation of political opponents has increased (including the detention of the former president, Thomas Boni Yayi). ${ }^{7}$

In 2018, Houngue was arrested and charged with embezzling public funds. In March 2019, the Investigating Committee of the Court for the Repression of Economic Crimes and Terrorism (CRIET) referred him to the Correctional Chamber of that Court with a new charge for complicity in the abuse of office. He was convicted, and on July 25, 2019, he was sentenced to ten years' imprisonment. The detention that led to Houngue's conviction before the CRIET is illustrative of a wider crackdown against opposition politicians in Benin. Indeed, the delegitimization of the opposition is a common strategy among incumbent political figures in Africa. ${ }^{8}$

Under the new electoral system ushered in by the Revised Constitution and Amended Electoral Code, political parties must pay 249 million CFA francs (approximately $\$ 400,000)$ to field candidates in parliamentary elections. In addition, parties have to secure 10 percent of the total national vote to enter the legislature, forcing local parties to build a national presence. The only two parties that met the criteria to win seats in Parliament in 2019-the Republican Bloc and the Progressive Union - were both loyal to the president. The stringent eligibility criteria created additional hurdles making it more difficult for opposition parties to field candidates. While President Talon argued that a tougher threshold would enhance Benin's fragmented Parliament, critics, including Houngue, condemned the move as constricting free association and participation in democratic governance.

\footnotetext{
${ }^{4}$ My approach contrasts views like those expressed by Kal Raustiala that focus strictly on compliance with the decision of the court as a measure of effectiveness. Kal Raustiala, Compliance and Effectiveness in International Regulatory Cooperation, 32 CASE WEST. RES. J. INT'L L. 387, 393 (2000). For alternative approaches that resonate with the argument in this case note, see James Gathii, Introduction, in The Performance of Africa's INTERNATIONAL COURTS, supra note 2, at 4 (arguing that Africa's international courts have broader impacts beyond focusing on compliance and effectiveness); Yuval Shany, Assessing the Effectiveness of International Courts: A GoalBased Approach, 106 AJIL 229 (2012) (contending that each court has distinctive features and operates in a particular legal and political context, hence, a "goal-based definition of effectiveness is the most suitable for evaluating international court performance").

${ }^{5}$ Nic Cheeseman, Democracy in Africa: Successes, Failures and the Struggle for Political Reform 182 (2015).

${ }^{6}$ Stephen Paduano, The Fall of a Model Democracy, ATLANTIC (May 28, 2019), at https://www.theatlantic.com/ international/archive/2019/05/benin-west-africa-model-democracy-fall/590377. The Benin narrative is comparable to the Tanzanian example. See Jonathan W. Rosen, Tanzania Was East Africa's Strongest Democracy. Then Came "The Bulldozer," AтLANTiC (May 14, 2019), at https:/www.theatlantic.com/international/archive/2019/05/ tanzania-president-upended-strong-east-africa-democracy/589339.

${ }^{7}$ Sarah Maslin Nir, It Was a Robust Democracy. Then the New President Took Power., N.Y. Times (July 4, 2019), at https://www.nytimes.com/2019/07/04/world/africa/benin-protests-talon-yayi.html.

${ }^{8}$ Darin Christensen $\&$ David D. Laitin, African States Since Independence: Order, Development, \& DeMOCRACY 282-97 (2019).
} 
The municipal elections of May 2020 continued the democratic erosion in Benin, further shrinking space for political opposition. ${ }^{9}$ The elections were conducted amidst protests by many Beninese and during the COVID-19 pandemic. The only opposition party to participate-Forces Cauris pour un Bénin Emergent (FCBE)—won a majority in seven out of Benin's seventy-seven municipalities. These municipal elections have direct consequences for the presidential election slated for April 2021. ${ }^{10}$ Pursuant to Article 44 of the Revised Constitution, which was passed by a national assembly (composed solely of elected representatives of the party in power), presidential and vice-presidential candidates are required to be sponsored by at least sixteen parliamentarians and/or mayors.

From the foregoing, it is evident that the April 2021 presidential elections would be conducted in the shadow of an executive intolerant of opposition, questionable parliamentary elections, and dubious independence of the Constitutional Court and electoral commission.

After the case was filed, the African Court on Human and Peoples' Rights (African Court) ordered provisional measures in favor of Houngue on two separate occasions. The operative parts of the African Court's first provisional measure were that Benin stay the execution of the CRIET decision until it pronounced its own final judgment, and that Benin report on the implementation of the order within thirty days (para. 30). ${ }^{11}$ The second interim measure was prompted by Benin's failure to comply with the order arising from the first provisional measure, and required Benin to take all necessary measures to effectively remove any administrative, judicial, and political obstacles to Houngue's candidacy in the forthcoming elections (para. 9). ${ }^{12}$

In the substantive arguments before the African Court, Houngue alleged, inter alia, a violation of his right to appeal the CRIET judgment under Universal Declaration of Human Rights (UDHR) Article 10, African Charter on Human and Peoples' Rights (Charter) Article 7(1)(a), and International Covenant on Civil and Political Rights (ICCPR) Article 2(3) (para. 6). ${ }^{13}$ Houngue argued that by requiring Beninese citizens to vote only for candidates chosen and endorsed by political parties, Article 153-1 of the Revised Constitution violates the right to freedom of expression as enshrined in ICCPR Article 19(2). Further, he argued that Benin's actions violated various regional and international human rights instruments protecting the freedoms of association and expression, and the right to nondiscrimination. ${ }^{14}$ In his request for relief,

\footnotetext{
${ }^{9}$ Ella Jeannine Abatan \& Michaël Matongbada, Benin's Local Elections Further Reduce the Political Space, INST. SEC. STUD. (May 27, 2020), at https://issafrica.org/iss-today/benins-local-elections-further-reduce-the-politicalspace

${ }^{10}$ Benin President Patrice Talon to Face Two Rivals in April Election, France24 (Feb. 13, 2021), at https://www. france24.com/en/africa/20210213-benin-president-patrice-talon-to-face-two-rivals-in-april-election.

${ }^{11} \mathrm{Id}$.

${ }^{12}$ Houngue Éric Noudehouenou v. Republic of Benin, App. No. 003/2020 HEN, Ruling, Provisional Measures - 2 (Afr. Ct. Hum. Peoples' Rts. Sept. 25, 2020), available at https:/www.african-court.org/en/ images/Cases/Orders/Appl._003-2020_-_Houngue_Erc_-_RULING__Engl.pdf.

${ }^{13} \mathrm{He}$ also contended that he was prohibited from filing an appeal under Article 19 of the 2018-13 Act of July 2 establishing CRIET. Houngue Éric Noudehouenou v. Republic of Benin, App. No. 004/2020 HEN, Ruling, Provisional Measures, paras. 7-9 (Afr. Ct. Hum. Peoples' Rts. May 6, 2020), available at https://www.africancourt.org/en/images/Cases/RulingOnJurisdiction/Appl.004-2020-Houngue-Eric-NoudeHouenou-v-BeninOrder-on-provisional-measures.pdf.

${ }^{14}$ See, e.g., African Charter on Human and Peoples' Rights, Arts. 3 (right to equal protection), 13 (right to effective remedy), June 27, 1981, CAB/LEG/67/3 rev. 5, 21 ILM 58 (1982); Universal Declaration of Human Rights, Arts. 7 (equal protection), 20 (freedom of association), Dec. 10, 1948, GA Res. 217 A (III); International Covenant on Civil and Political Rights, Arts. 2(3), 26, Dec. 16, 1966, 999 UNTS 171.
} 
Houngue asked the African Court for an order mandating that Benin take all necessary constitutional, legislative, and associated measures to end these alleged violations in advance of the forthcoming elections, and report to the Court. Benin argued that that the Court lacked jurisdiction to scrutinize or annul its Constitution and Electoral Code (para. 14). In the alternative, the government contended that the matter was inadmissible as Houngue lacked the locus standi to initiate the proceeding. Lastly, Benin asked for a declaration that it did not violate any of Houngue's human rights.

In its judgment, the African Court held that it had material jurisdiction over the case (para. 28). It was enough that the human rights violations arose out of the Charter and other international human rights instruments ratified by Benin. Further, the Court found that Houngue had exhausted local remedies and fulfilled the conditions for admissibility (para. 52).

The Court made four findings regarding alleged human rights violations. First, it found that Benin did not violate Houngue's right to an effective remedy (para. 93). Second, however, it did find that Benin violated its obligation under Article 10(2) of the African Charter on Democracy, Election and Good Governance (ACDEG) because Benin's constitutional amendment process was not based on national consensus (para. 119). ${ }^{15}$ Notably, "[ $t$ ]he fact that the Revised Constitution was passed unanimously cannot conceal the need for national consensus driven by the ideals that prevailed during the adoption of the Constitution of 11 December 1990' and . . the ACDEG."16 Third, in view of Benin's noncompliance with the ACDEG process for the amendment of the Constitution, the African Court found it was unnecessary to rule on the alleged violations of rights to participate in public affairs, equality, freedom of association, freedom of religion, and freedom of expression as envisaged under the Revised Constitution (para. 79). According to the Court, "it is superfluous to give a detailed ruling on violations that would result from any of the revised articles because the Constitutional revision as a whole violates Article 10(2) of the ACDEG" (para. 78). ${ }^{17}$ Fourth, the Court found that Benin violated the right of Houngue to be presumed innocent under UDHR Article 11 and Article 13(3) of the Charter (para. 105). Consequently, the African Court ordered Benin to take all measures to repeal the law revising the 1990 Constitution and all subsequent laws relating to the election pursuant to that revision in order to guarantee that its citizens, including Houngue, participate freely in the forthcoming presidential election.

A paramount outcome of the remedy ordered by the African Court is the declaration that the process leading to the constitutional revision in Benin was invalid. While Houngue did not seek a monetary remedy, the African Court's order that Benin "take all necessary measures to ensure cessation of all effects of the constitutional revision and the violations which the court found" is an unprecedented step in the Court's jurisprudence on remedies

\footnotetext{
${ }^{15}$ Article 10(2) of the African Charter on Democracy, Election and Good Governance (ACDEG) requires: "State Parties shall ensure that the process of amendment or revision of their constitution reposes on national consensus, obtained if need be, through referendum."

${ }^{16}$ Houngue Éric Noudehouenou v. Republic of Benin, App. No. 003/2020, Judgment, supra note 1, para. 65.

${ }^{17}$ Id., para. 7.
} 
(para. 123(xv)). ${ }^{18}$ In this context, Houngue's case not only reinforces the bold position of the African Court in indicating that constitutional changes may be required to give effect to its judgments, but also broadens the nature of the remedy that it issues.

To understand the broader socio-political and legal context of Houngue's case, one has to see it as part of a wider and growing mobilization of the African Court by opposition politicians as an alternative forum for engaging in political warfare against repressive national governments and for mobilizing social movements. ${ }^{19}$ Like its sister subregional courts, the African Court does not have jurisdiction to review election disputes arising out of political processes in its member states. ${ }^{20}$ However, for over a decade, political stakeholders and civil society actors have transformed Africa's subregional courts into alternative fora for resistance and protest against their governments. ${ }^{21}$ Opposition politicians and dissidents have utilized the supranational human rights complaint as a lever to judicialize election disputes. Such strategic human rights litigation before the African Court in particular is on the rise.

The strategic litigation of human rights violations arising from electoral processes provides a tool in the pursuit of social change. This strategy is most obviously employed by opposition parties and candidates, like Houngue. Pro-democracy and civil society groups have also increasingly turned to human rights litigation in Africa's regional and subregional courts as a form of activism aimed at consolidating democratic governance. All this is redefining the boundaries of the dockets of these courts. ${ }^{22}$

The openness of Africa's regional and subregional courts to these sorts of disputes enhances the wider sociopolitical opportunities of pro-democracy activists and civil society. The rationale for the judicialization of political disputes arising from electoral processes or constitutional amendments relating to the law of democracy is not simply about emerging victorious in the particular case. Political disputes are judicialized in the African Court as a means of mobilizing social change, diversity of opposition voices in politics, and defense of political freedom. Even where applicants lose the case, strategic litigation can have significant instrumental value. ${ }^{23}$ For example, through coordinated efforts with the media, litigants use such cases to launch campaigns to pressure their governments to act as law-abiding members of the international community. ${ }^{24}$

\footnotetext{
${ }^{18}$ Compare this to the first merits decision by the Court in Christopher Mtikila \& Ors. v. Tanzania, which confirmed its powers to issue compensation and reparations. Christopher Mtikila \& Ors. v. Tanzania, App. Nos. 009/2011, 011/2011, Judgment (Afr. Ct. Hum. Peoples' Rts. June 14, 2013), available at https://www.african-court.org/en/images/Cases/Judgment/Judgment\%20Application\%20009-011-2011\%20 Rev\%20Christopher\%20Mtikila\%20v.\%20Tanzania.pdf; Oliver Windridge, A Watershed Case for African Human Rights: Mtikila and Others v. Tanzania, Oxford Hum. Rts. Hub Blog (Feb. 17, 2015), at https://ohrh.law.ox.ac.uk/a-watershed-case-for-african-human-rights-mtikila-and-others-v-tanzania.

${ }^{19}$ Olabisi D. Akinkugbe, Towards an Analysis of the Mega-political Jurisprudence of the ECOWAS Community Court of Justice, in The Performance of Africa's International Courts, supra note 2; Gathii \& Mwangi, supra note 2; Adem Kassie Abebe, Taming Regressive Constitutional Amendments: The African Court as a Continental (Super) Constitutional Court, 17 InT'L J. Const. L. 89 (2019).

${ }^{20}$ Frans Viljoen, Understanding and Overcoming Challenges in Accessing the African Court on Human and Peoples' Rights, 67 INT'L \& Comp. L. Q. 63 (2018).

${ }^{21}$ Gathii, supra note 4.

22 Open Society Justice Initiative, Strategic Litigation Impacts: Insights from Global Experience (2018), available at https://www.justiceinitiative.org/uploads/fd7809e2-bd2b-4f5b-964f-522c7c70e747/strategic-litigationimpacts-insights-20181023.pdf.

${ }^{23}$ Akinkugbe, supra note 19.

${ }^{24}$ Gathii \& Mwangi, supra note 2.
} 
However, strategic human rights litigation can also have negative consequences for the ability of nonstate litigants to access the African Court. ${ }^{25}$ The growing litigation of high-profile political disputes before that Court occurs, after all, in the shadow of executive consolidation and intimidation. Successful invocations of the human rights framework have already generated consequential reactions by member states - including the withdrawal of optional declarations granting individuals and NGOs direct access to the African Court. ${ }^{26}$ Houngue's case was no exception. On March 25, 2020, shortly after its defeat, Benin withdrew its declaration granting individuals direct access to the Court. Benin argued that the Court exceeded its jurisdiction in intervening in its sovereign constitutional matters. ${ }^{27}$ (Benin's withdrawal will not be effective until March 2021 and would neither affect pending cases nor prevent new cases from being filed before then.)

The judgment in Houngue Éric Noudehouenou v. Republic of Benin contributes to the density of megapolitical jurisprudence of Africa's regional and subregional courts-a term meant to capture high-profile cases arising from national electoral processes, electoral procedures, good governance and the rule of law, constitutional and electoral law amendments, and regime change. ${ }^{28}$ These disputes are always embedded in broader national sociopolitical contestations. The strength of megapolitical disputes lies in their instrumental and nonmaterial value and the changes that they prompt. These cases are instrumental in every phase, as they present the litigants with sustained leverage to pressure the government through the media.

Looking forward, to consolidate and maximize the sociopolitical benefits of the opportunities created by megapolitical disputes for social movements, litigants and activists must coordinate and cross-fertilize the jurisprudence of the African Court and other subregional courts. For example, in the context of the Economic Community of West African States Court of Justice (ECOWAS Court), the Ugokwe doctrine sets an important precedent defining

\footnotetext{
${ }^{25}$ Human rights violations are judicialized before the African Court either directly, where the optional declaration prescribed under Article 34(6) has been deposited with the African Union Commission, or indirectly, as a result of reference from the African Commission on Human and Peoples' Rights.

${ }^{26}$ Sègnonna Horace Adjolohoun, A Crisis of Design and Judicial Practice? Curbing Disengagement from the African Court on Human and Peoples' Right, 20 Afr. Hum. RTS. L.J. 1 (2020); Nicole De Silva \& Misha Plagis, A Court in Crisis: African States'Increasing Resistance to Africa's Human Rights Court, OpINIO Juris (May 5, 2020), at http://opiniojuris.org/2020/05/19/a-court-in-crisis-african-states-increasing-resistance-to-africas-humanrights-court; Frans Viljoen \& Michael Nyarko, Centre for Human Rights Expresses Concern About the Withdrawal of Direct Individual Access to the African Court by Benin and Côte D'Ivoire, CTr. Hum. RTs. (May 5, 2020); available at https://www.chr.up.ac.za/images/centrenews/2020/Centre_for_Human_Rights_ expresses_concern_about_the_withdrawal_of_direct_individual_access_to_the_African_Court_by_Benin_and_ 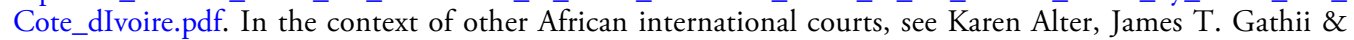 Laurence R. Helfer, Backlash Against International Courts in West, East and Southern Africa: Causes and Consequences, 27 EUR. J. INT'L L. 293 (2016).

${ }^{27}$ According to the Benin minister of justice and legislation, Sévérin Quenum, the withdrawal is justified because: "For several years now, certain rulings make by the African Court of Human and People's Rights have given grave cause for concern because of severe anomalies which have driven Tanzania, its host country, and Rwanda, to withdraw from participation over individual and NGO access arrangements." Quoted in Abdoulaye Bah \& Adam Long, Benin's Partial Withdrawal from African Charter of Human Rights Is a Retreat from Democracy, GLoB. Volces (May 7, 2020, at https://globalvoices.org/2020/05/07/benins-partial-withdrawal-from-african-charter-of-human-rights-is-a-retreat-from-democracy.

${ }^{28}$ Akinkugbe, supra note 19 , at 150.
} 
the circumstances in which election disputes come under its jurisdiction. ${ }^{29}$ It asserts that even if the legal texts applicable to the relevant court

confer no general or specific power to adjudicate election disputes or matters arising therefrom, in appropriate cases, the [ECOWAS] Court will assume jurisdiction where the determination of the human rights of the parties are intertwined with mega-political disputes. ${ }^{30}$

Intentionally cross-incorporating the wider megapolitics jurisprudence of the different regional and subregional courts would enhance their role as actors in norm-generation and development of their own common law. ${ }^{31}$ Professional organizations can collaborate with civil rights groups and pro-democracy advocates to advance the norms of sociopolitical movement in pursuit of legal reforms and social change. For example, the work of the Pan African Lawyers Union (PALU) illustrates the role that professional organizations can play in supporting public interest and strategic litigation with a view to not only cross-fertilizing the jurisprudence of the courts, but also, bringing valuable knowledge, skills, and experience to megapolitics disputes before the court. ${ }^{32}$ In this regard, the density of the megapolitical decisions bodes well for the consolidation of strategic litigations as a tool for social and political mobilization.

In conclusion, Houngue Eric Noudehouenou v. Republic of Benin shows the growing strategy that opposition politicians and political parties adopt in mobilizing legal reforms through social movements before the African regional and subregional courts. The strategic nature of the litigation does not map on to the traditional narratives about the implementation and effectiveness of international judicial decisions. Yet, it is effective in an important way. Based on strategically orchestrated international and national media attention, litigants can bring extraordinary pressure on national governments. To avoid "naming and shaming" in national and international media, an otherwise authoritarian executive may allow legal reforms to proceed. ${ }^{33}$ It is too early to say how the Noudehouenou case will end. But it tends to illustrate how strategic litigation of megapolitical cases in Africa's regional and subregional courts is growing in importance as a tool for sociopolitical movements and ultimately as a driver for legal and political reform.

Olabisi D. AKINKUGBE Dalhousie University Schulich School of Law doi:10.1017/ajil.2021.16

${ }^{29}$ Jerry Ugokwe v. The Federal Republic of Nigeria and Christian Okeke, No. ECW/CCJ/JUD/03/05, Judgment (ECOWAS Ct. Oct. 7, 2005).

${ }^{30}$ Akinkugbe, supra note 19 , at 158

${ }^{31}$ Martha Finnemore \& Kathryn Sikkink, International Norm Dynamics and Political Change, 52 INT'L OrG. 887 (1998).

32 The Pan African Lawyers Union (PALU), at https://lawyersofafrica.org/about/what-palu-does.

${ }^{33}$ Emilie M. Hafner-Burton, Sticks and Stones: Naming and Shaming the Human Rights Enforcement Problem, 62 INT'L ORG. 689 (2008). 